\title{
A new approach to enantiopure $\beta$-endo-substituted azabicyclic proline analogues by base induced epimerization of a formyl derivative
}

\author{
Ana M. Gil, ${ }^{a}$ Elena Buñuel, ${ }^{b^{*}}$ and Carlos Cativiela ${ }^{\mathbf{a}^{*}}$ \\ ${ }^{a}$ Departamento de Química Orgánica, ICMA, Universidad de Zaragoza-CSIC, 50009 \\ Zaragoza, Spain \\ E-mail: cativiela@unizar.es \\ ${ }^{b}$ Departamento de Química Orgánica, Universidad Autónoma de Madrid, 28049 Madrid, Spain \\ E-mail: elena.bunnuel@uam.es
}

Dedicated to Professor Joan Bosch on the occasion of his $60^{\text {th }}$ birthday

\begin{abstract}
The $\beta$-epimer of methyl $(1 S, 2 R, 4 R)-N$-benzoyl-2-formyl-7-azabicyclo[2.2.1]heptane-1carboxylate, $(1 S, 2 S, 4 R)-7$, has been obtained by treatment of the exo-formyl derivative with triethylamine in methanol. The development of this epimerization procedure has further increased the already wide possibilities offered by our methodology and solves the problem of access to the endo derivatives that would result from the Diels-Alder reaction of Danishefsky's diene and the C-4 unsaturated E-oxazolones, whose preparation frequently proves to be problematic.
\end{abstract}

Keywords: Constrained proline, $\alpha$-amino acids, 7-azabicyclo[2.2.1]heptane, epimerization

\section{Introduction}

The introduction of rigidity into bioactive peptides has proven to be a useful tool to study the conformational requirements for biological activity. ${ }^{1}$ Proline and analogues are well known for their ability to introduce conformational restrictions into bioactive peptides by inducing the formation of $\beta$-turns as well as influencing the protein folding. ${ }^{2}$ The replacement of proline with more constrained analogues provides additional information about receptor recognition and affinity.

Initial results showing the benefits of replacing proline with analogues containing a 7azabicyclo[2.2.1] heptane skeleton (2,5-ethanoproline), ${ }^{3}$ along with the increasing interest in structural studies of $\beta$-substituted prolines, ${ }^{4}$ encouraged us to intensify our synthetic efforts on 
the development of a versatile methodology for the synthesis of enantiopure $\beta$-substituted proline analogues with the 7-azanorbornane skeleton - a special kind of amino acid in which the rigidity provided by the azabicyclic skeleton is combined with the presence of a $\beta$-substituent that mimics the $\alpha$-amino acid side chain.

On the other hand, the discovery of epibatidine - an alkaloid with exceptional biological properties and possible clinical applications - by Daly and co-workers in $1992^{5}$ has led to efforts to construct such ring systems. ${ }^{6}$ However, very few procedures have been described to date on the synthesis of enantiomerically pure proline analogues containing the azabicyclic ring, ${ }^{7}$ a fact that provided more than enough reason to justify our interest in these systems.

Our main objective in this study was the development of a versatile and efficient methodology for the synthesis of both enantiomers of a wide variety of azabicyclic prolines with a $\beta$-substituent in an exo disposition. ${ }^{7 \mathrm{f}-\mathrm{h}, 8}$ As part of our current research project devoted to determining the conformational preferences of constrained analogues of non-proteinogenic amino acids when incorporated into a peptide chain, ${ }^{9}$ we evaluated the structural consequences arising form the replacement of the proline residue in peptide models by these proline- $\alpha$-amino acid chimeras. ${ }^{3 \mathrm{c}, 3 \mathrm{~d}}$

The promising results reported in this recent study focused our interest on extending the developed methodology to the synthesis of a new series of $\beta$-endo-substituted azabicyclic prolines as a source of surrogates to be incorporated into model peptides whose structural and biological study would shed light on the nature of the effects induced by this type of conformational restriction and the influence of the absolute configurations of the stereogenic centers.

\section{Results and Discussion}

Recently, we developed a new route for the synthesis of a wide variety of enantiomerically pure exo-2-substituted 7-azabicyclo[2.2.1] heptane-1-carboxylic acid derivatives. This approach allowed a racemic and an asymmetric version to be applied in a complementary manner. Our overall strategy is based on the preparation of valuable azabicyclic intermediates through a key step that involves cyclization of cyclohexylamine derivatives obtained from the transformation of the cycloadducts provided by the Diels-Alder reaction of C-4 unsaturated 5(4H)-oxazolones and Danishefsky's diene.

The cycloaddition of Danishefsky's diene and (Z)-2-phenyl-4-benzylidene-5(4H)oxazolone (Z)-1 or (Z)-2-phenyl-4-(thien-2-ylmethylene)-5(4H)-oxazolone (Z)-2, followed by manipulation of the resulting adducts, has allowed the multigram-scale synthesis of a racemic mixture of methyl $N$-benzoyl-2-exo-(phenyl)-7-azabicyclo[2.2.1] heptane-1-carboxylate (rac-exo$3)^{8 \mathrm{a}}$ and methyl $\mathrm{N}$-benzoyl-2-exo-(thien-2-yl)-7-azabicyclo[2.2.1]heptane-1-carboxylate (racexo-4), ${ }^{8 b}$ respectively (Scheme 1). Once the synthesis of the racemic compounds had been achieved, we undertook the isolation of the enantiopure compounds on a preparative scale by 
HPLC resolution using a non-commercial chiral stationary phase, which provided each enantiomer separately with high efficiency.<smiles>[R]C=C1N=C(c2ccccc2)OC1=O</smiles>

$\mathrm{R}=$ phenyl $(Z)-1$

$\mathrm{R}=$ thien-2-yl (Z)-2

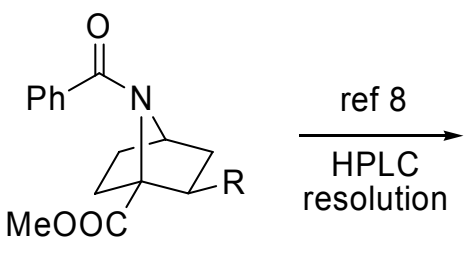

rac-exo-3 rac-exo-4

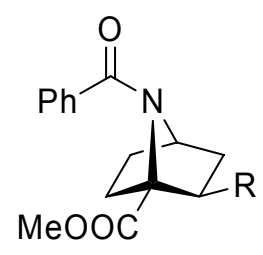

$(1 S, 2 S, 4 R)-3$

(1S,2R,4R)-4<smiles>[R]C1CCC2(C(=O)OC)CCC1N2C(=O)c1ccccc1</smiles>

$(1 R, 2 R, 4 S)-3$ $(1 R, 2 S, 4 S)-4$

\section{Scheme 1}

The extension of our methodology to an asymmetric version starting from the chiral C-4 unsaturated oxazolone 5, which is derived from $(R)$-glyceraldehyde, allowed the stereoselective synthesis of methyl (1S,2R,4R)- $N$-benzoyl-2-[(S)-2,2-dimethyl-1,3-dioxolan-4-yl]-7azabicyclo[2.2.1] heptane-1-carboxylate (6), another enantiopure key intermediate on a 40 gram scale (Scheme 2). ${ }^{7 \mathrm{f}-\mathrm{h}}$

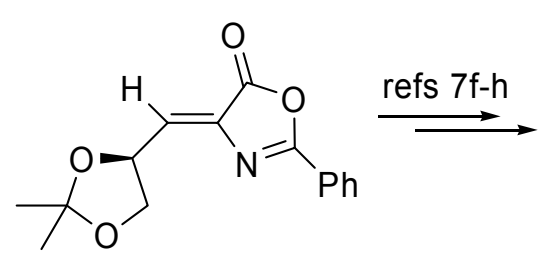

(Z)-5

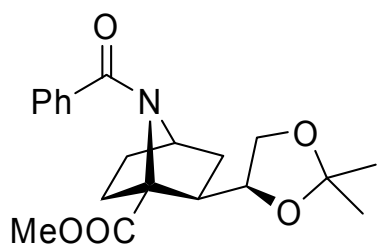

$(1 S, 2 R, 4 R)-6$

\section{Scheme 2}

As described previously, compounds 3,4 and $\mathbf{6}$ in enantiomerically pure form have proven to be very useful intermediates for the synthesis of a wide variety of $\beta$-substituted azabicyclic prolines in an exo disposition due to the transformation into other synthetically flexible functions such as formyl or hydroxymethyl groups (Scheme 3). ${ }^{8,10}$ As we have demonstrated in previous studies, this stereocontrolled functionalization offered extensive choice for subsequent transformations on the amino acid side chain. Olefination reactions and $\mathrm{S}_{\mathrm{N}} 2$ displacements at the $\gamma$-position have generated a wide range of possibilities for the preparation of a very special type of amino acids in which the rigidity provided by the azabicyclic skeleton is combined with the presence of a $\beta$-substituent, which mimics the $\alpha$-amino acid side chain (Scheme 3). ${ }^{10,11}$ 

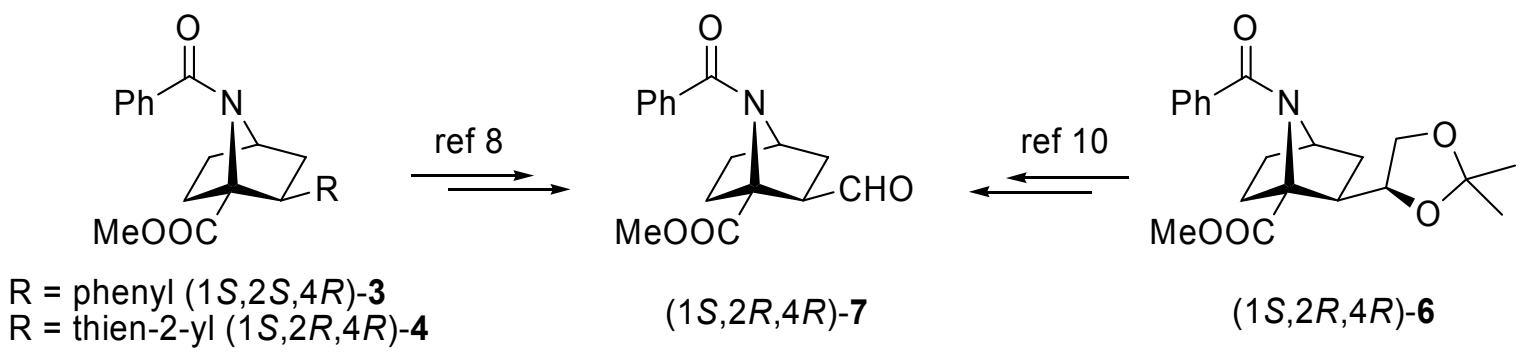

$$
\begin{aligned}
& \mathrm{R}=\text { phenyl }(1 S, 2 S, 4 R)-3 \\
& \mathrm{R}=\text { thien-2-yl }(1 S, 2 R, 4 R)-4
\end{aligned}
$$

$(1 S, 2 R, 4 R)-7$

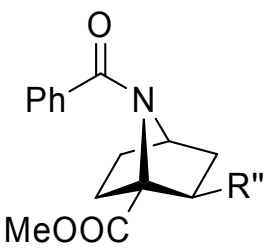

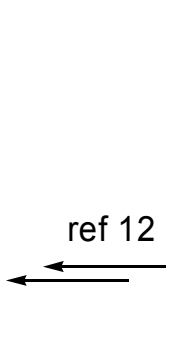

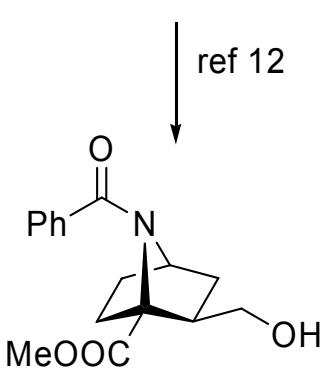

$(1 S, 2 R, 4 R)-8$
$(1 S, 2 R, 4 R)-6$

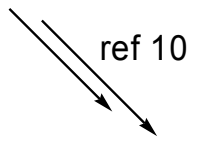

\section{Scheme 3}

Taking into account the efficacy of the established synthetic method, our next aim was to extend the approach to the synthesis of the corresponding enantiomerically pure endo stereoisomers of $\beta$-substituted prolines that incorporate the 7 -azanorbornane core. In principle, access to these compounds would involve the use of the corresponding C-4 unsaturated 5(4H)oxazolone as the starting material, but according to our previous experience the synthesis of the dienophile is, to say the least, problematic and under classical Diels-Alder conditions isomerization to the most stable $Z$-isomer occurs, giving rise to a complex mixture of cycloadducts. ${ }^{12}$

During the course of our previous studies, we found that intermediate $(1 S, 2 R, 4 R)-7$ proved to be exceedingly susceptible to base-induced epimerization. In fact, oxidation of alcohol $(1 S, 2 R, 4 R)-8$ under Swern conditions with oxalyl chloride, $\mathrm{Et}_{3} \mathrm{~N}$ and DMSO in dichloromethane provided a $70: 30$ mixture of the $\beta$-formyl derivative $(1 S, 2 R, 4 R)-7$ and its $\mathrm{C}-2$ epimer in $97 \%$ combined yield. ${ }^{8 \mathrm{a}}$ On the other hand, in the study of the Wittig reaction of $(1 S, 2 R, 4 R)-7$ some of the conditions led to a mixture of $\mathrm{C}-2$ epimeric products due to partial epimerization at $\mathrm{C}-2 .{ }^{10}$ The ease with which this intermediate undergoes epimerization at the stereocenter adjacent to the aldehyde group prompted us to explore its potential utility to achieve our objective.

To the best of our knowledge, the literature reports only epimerization procedures in a 7azabicyclo[2.2.1] heptane skeleton applied to the synthesis of the thermodynamically more stable exo-epibatidine derivatives. ${ }^{13}$ The notoriously problematic epimerization of endo-epibatidine to the corresponding exo-isomer using potassium tert-butoxide in refluxing tert-butyl alcohol was finally improved by simply using microwave irradiation in the presence of potassium tertbutoxide in tert-butanol. ${ }^{13 \mathrm{~d}}$ However, attempts to bring about epimerization of other epibatidine 
analogues using standard protocols $\left(\mathrm{K}_{2} \mathrm{CO}_{3} / \mathrm{MeOH}, \mathrm{NaH} / \mathrm{THF}, p\right.$-TsOH/toluene, $\left.{ }^{\mathrm{t}} \mathrm{BuOK} /{ }^{\mathrm{t}} \mathrm{BuOH}\right)$ failed and in this case a silica gel-catalyzed epimerization was found to be the best procedure. ${ }^{13 \mathrm{~g}}$ In accordance with these reports and taking into account the highly favorable exo-epimerization under thermodynamic conditions, we decided to evaluate the opposite epimerization process at C-2 of the exo-formyl derivative $(1 S, 2 R, 4 R)-7$ at low temperatures in an effort to provide the kinetically controlled product.

In this context, we started the epimerization study using $\mathrm{NaH}$ as a base in dry THF and the reaction was performed at $-78{ }^{\circ} \mathrm{C}$ over a range of reaction times. However, these conditions afforded only the starting material without the presence of any epimerization product. Therefore, we decided to increase the reaction temperature and when the reaction was carried out at $-20{ }^{\circ} \mathrm{C}$ a 39/61 mixture of the endo and exo stereoisomers was obtained. The reaction mixtures resulting from the evaporation of the solvent were analysed by ${ }^{1} \mathrm{H}$ NMR spectroscopy, and the determination of the endo/exo ratio was carried out by integration of the signals of the aldehyde proton (10.01 and $9.89 \mathrm{ppm}$ for the endo and exo-isomers, respectively) and the methyl carboxylate (3.87 and $3.80 \mathrm{ppm}$ for the endo and exo-isomers, respectively) in the ${ }^{1} \mathrm{H}$ NMR spectrum of the crude material. In order to improve the epimerization ratio, the reaction mixture was allowed to warm up to room temperature after addition of the base at $-20{ }^{\circ} \mathrm{C}$ and this led to an increase in the proportion of the endo epimer of aldehyde 7 to a 55/45 ratio. Unfortunately, all attempts to improve the epimerization process by increasing the reaction time to room temperature failed, resulting only in the decomposition of the starting material. Similar results were obtained when aldehyde $(1 S, 2 R, 4 R)-7$ was allowed to react with LDA in dry THF, but in this case the best rate of epimerization was reached at $-20{ }^{\circ} \mathrm{C}$ (endo/exo: $\left.45 / 55\right)$ and an increase in the reaction temperature proved unsuccessful for any reaction time.

All our epimerization efforts proved unsuccessful and we therefore planned to study the epimerization process using the reported procedures. Initially, we tried potassium tert-butoxide and the reaction of $(1 S, 2 R, 4 R)-7$ with this base in dry tert-butyl alcohol at room temperature resulted in the decomposition of the starting material after only 30 minutes of reaction. In contrast, the use of potassium carbonate in THF/water under reflux afforded a 55/45 mixture of the endo/exo epimers but in very low overall yield due to saponification of the methyl carboxylate substituent at C-1.

Finally, due to the lack of satisfactory results and the known problems associated with epimerization when an epimerization-prone aldehyde is obtained under Swern conditions using $\mathrm{Et}_{3} \mathrm{~N}$ as base, ${ }^{14}$ we decided to explore the behavior of this base in the epimerization study.

Treatment of derivative $(1 S, 2 R, 4 R)-7$ with $\mathrm{Et}_{3} \mathrm{~N}$ using methanol as a solvent at room temperature for 4 days gave a 70/30 mixture of the endo/exo isomers in the crude reaction mixture, as determined by integration of the ${ }^{1} \mathrm{H}$ NMR signals. These satisfactory results encouraged us to investigate this reaction under several sets of reaction conditions. However, the ratio did not change when the reaction time was extended (more than 30 days). We therefore decided to explore the reaction at $40{ }^{\circ} \mathrm{C}$, but the ratio of epimerization was the same as before and the ${ }^{1} \mathrm{H}$ NMR spectrum of the crude reaction mixture contained other signals (which were not 
characterized). Finally, reaction of the aldehyde with a large excess of $\mathrm{Et}_{3} \mathrm{~N}$ (using this reagent as a solvent) did not lead to a better epimerization ratio.

On the basis of these results, we decided to attempt the isolation of the two epimers. The chromatographic separation of the resulting mixtures (70/30) on silica gel using hexane/ethyl acetate as eluent in a gradient form (6:4 to $1: 1)$ furnished the major stereoisomer $(1 S, 2 S, 4 R)-7$ in enantiomerically pure form and allowed the recovery of the starting material $(1 S, 2 R, 4 R)-7$ (Scheme 4).

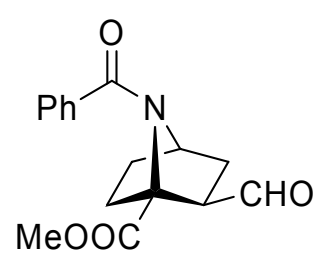

$(1 S, 2 R, 4 R)-7$

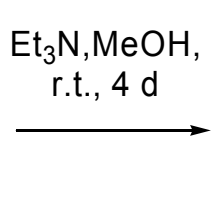

endo/exo-7 (70/30)

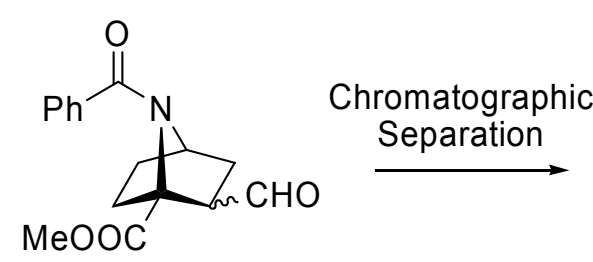

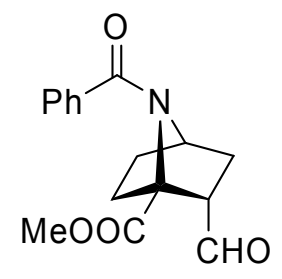

$(1 S, 2 S, 4 R)-7$

$66 \%$

\section{Scheme 4}

In this way we have established an efficient synthetic method for the preparation of the desired aldehyde $(1 S, 2 S, 4 R)-7$ in enantiomerically pure form.

Once the epimerization conditions had been optimized, we decided to begin a program aimed at preparing the series of endo-derivatives by using stereo controlled procedures and with the new intermediate $(1 S, 2 S, 4 R)-7$ as the starting material.

Firstly, as an example of the versatility of the methodology, we studied the transformation of aldehyde $(1 S, 2 S, 4 R)-7$ into another functionalized intermediate - alcohol $(1 S, 2 S, 4 R)-\mathbf{8}$. As reported for the exo series, ${ }^{11}$ the reduction was achieved by treatment with $\mathrm{NaBH}_{4}$ in a methanol/water mixture to provide the primary alcohol in almost quantitative yield (97\%) (Scheme 5).

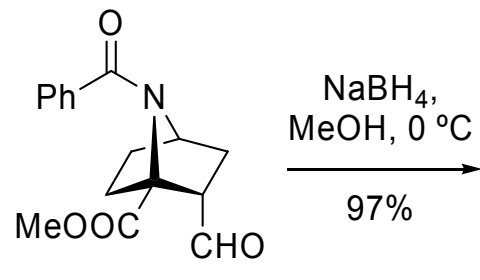

$(1 S, 2 S, 4 R)-7$

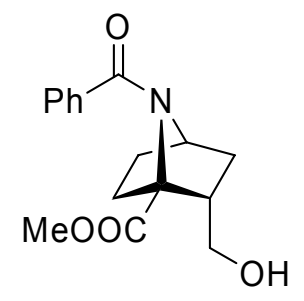

(1S,2S,4R)-8

\section{Scheme 5}


The rigorous proof of the assignment of the endo stereochemistry at C-2 was provided by single-crystal X-ray analysis of compound $(1 S, 2 S, 4 R)-\mathbf{8}$, as shown in Figure 1 . These data unambiguously demonstrate the endo configuration at the $\beta$-position of the azabicyclic skeleton.

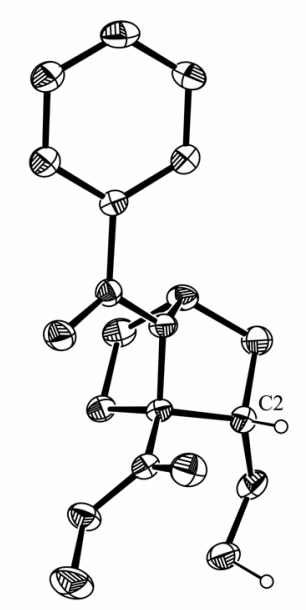

Figure 1. ORTEP drawing of compound $(1 S, 2 S, 4 R)$-8. Non-hydrogen atoms are represented by ellipsoids corresponding to $25 \%$ probability. The hydroxylic and C-2 hydrogens are represented by spheres of arbitrary size, the rest of the hydrogen atoms have been omitted for clarity.

Given the ready availability of epimerized alcohol $(1 S, 2 S, 4 R)-\mathbf{8}$ and in order to compare its reactivity with that of the $\beta$-epimer described in some of our previous papers, we decided to carry out a study of $\mathrm{S}_{\mathrm{N}} 2$ displacements at the $\gamma$-position.

The introduction of bromide, the leaving group that showed the best results in our previous work, was carried out by treatment of $(1 S, 2 S, 4 R)-8$ with $N$-bromosuccinimide and triphenylphosphine, which provided bromo derivative (1S,2S,4R)-9 in $80 \%$ yield (Scheme 6).

Finally, the behavior of bromide $(1 S, 2 S, 4 R)-9$ as a leaving group was studied by investigating displacement by hydride. The reaction of $(1 S, 2 S, 4 R)-9$ with sodium borohydride in HMPA under reflux afforded the corresponding derivative $(1 S, 2 S, 4 R)-\mathbf{1 0}$ in excellent yield.

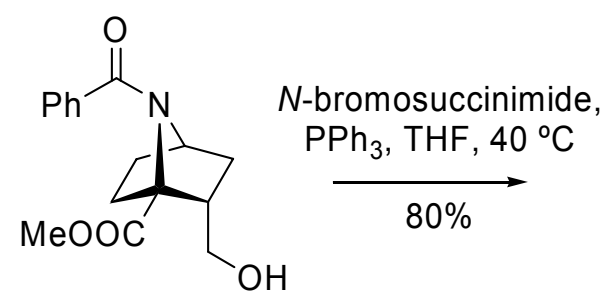

$(1 S, 2 S, 4 R)-8$

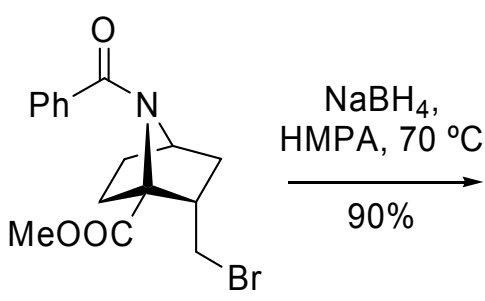

(1S,2S,4R)-9

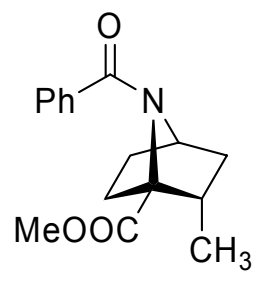

$(1 S, 2 S, 4 R)-10$

\section{Scheme 6}


In a similar manner, other transformations aimed at completing the family of endoderivatives are currently being studied in our laboratory and will be published in due course.

\section{Conclusions}

The work described here has extended our previously reported methodology to the synthesis of enantiomerically pure endo stereoisomers of $\beta$-substituted prolines that incorporate the 7azanorbornane skeleton.

To achieve this target, we studied the epimerization at C-2 of aldehyde $(1 S, 2 R, 4 R)-7$ and the subsequent transformation of the $\beta$-epimer $(1 S, 2 S, 4 R)-7$ into methyl $(1 S, 2 S, 4 R)$ - $N$-benzoyl-2methyl-7-azabicyclo[2.2.1] heptane-1-carboxylate $(1 S, 2 S, 4 R)-\mathbf{1 0}$. The excellent results obtained in this preliminary study offer a wide range of possibilities and clearly demonstrate the unquestionable potential of this methodology.

\section{Experimental Section}

General Procedures. Melting points were determined using a Büchi SMP-20 apparatus. IR spectra were registered on a Mattson Genesis FTIR spectrophotometer; $v_{\max }$ is given for the main absorption bands. ${ }^{1} \mathrm{H}$ and ${ }^{13} \mathrm{C}$ NMR spectra were recorded on a Bruker ARX-300 spectrometer at room temperature, using the residual solvent signal as the internal standard; chemical shifts $(\delta)$ are quoted in ppm, and coupling constants $(J)$ are measured in Hertz. Optical rotations were measured in a cell with a $10 \mathrm{~cm}$ pathlength at $25^{\circ} \mathrm{C}$ using a JASCO P-1020 polarimeter. The ESI mass spectra were recorded on a Bruker MicroTof-Q spectrometer. TLC was performed on Polygram $^{\circledR}$ sil G/UV254 precoated silica gel polyester plates and products were visualised under UV light (254 nm), anisaldehyde or phosphomolybdic acid developers. Column chromatography was performed using silica gel (Kieselgel 60). Methyl (1S,2R,4R)- $N$-benzoyl-2-formyl-7azabicyclo[2.2.1] heptane-1-carboxylate (7) was obtained according to the reported procedure. ${ }^{10}$

X-ray diffraction. The X-ray diffraction data were collected at room temperature on an Oxford Diffraction Xcalibur O diffractometer with a Sapphire CCD detector, using graphitemonochromated Mo-K $\alpha$ radiation $(\lambda=0.71073 \AA)$. The structure was solved by direct methods using SHELXS $97^{15}$ and refinement was performed using SHELXL $97^{16}$ by the full-matrix leastsquares technique with anisotropic thermal factors for heavy atoms.

Colorless single crystals of $(1 S, 2 S, 4 R)$-8 were obtained by slow evaporation from an ethyl acetate/ether solution. Reflections were measured in the $\omega / 2 \theta$ scan mode in the $\theta$ range $2.77-$ $26.00^{\circ}$. Hydrogen atoms were located by calculation (with the exception of the hydroxylic proton, which was found on the E-map) and affected by an isotropic thermal factor fixed to 1.2 times the Ueq value of the carrier atom (1.5 for the methyl protons). Crystallographic data: tetragonal, P41212; $\mathrm{a}=10.3837(1) \AA ; \mathrm{b}=10.3837(1) \AA, \mathrm{c}=26.8853(7) \AA ; \mathrm{Z}=8$; d (calcd.) = 
$1.326 \mathrm{~g} \mathrm{~cm}^{-3}$; reflections collected/independent: 36330/2854 [R(int) $\left.=0.0792\right]$; data/parameters: 2854/191; final $\mathrm{R}$ indices $[\mathrm{I}>2 \sigma(\mathrm{I})]: \mathrm{R}_{1}=0.0287 \mathrm{wR}_{2}=0.0458$; final $\mathrm{R}$ indices (all data): $\mathrm{R}_{1}=$ $0.0710, \mathrm{wR}_{2}=0.0491$.

Crystallographic data (excluding structure factors) for the structure of compound $(1 S, 2 S, 4 R)-8$ have been deposited with the Cambridge Crystallographic Data Centre as supplementary publication number CCDC 616701. Copies of the data can be obtained, free of charge, via http://www.ccdc.cam.uk/conts/retrieving.html or on application to CCDC, 12 Union Road, Cambridge CB2 1EZ, UK [fax: +44(0)-1223-336033 or e-mail: deposit@ccdc.cam.ac.uk].

Methyl (1S,2S,4R)- $N$-benzoyl-2-formyl-7-azabicyclo[2.2.1]heptane-1-carboxylate (7). To a solution of methyl $(1 S, 2 R, 4 R)-N$-benzoyl-2-formyl-7-azabicyclo[2.2.1]heptane-1-carboxylate (7) $(200 \mathrm{mg}, 0.70 \mathrm{mmol})$ in methanol $(5 \mathrm{~mL})$ was added triethylamine $(0.15 \mathrm{~mL}, 1.05 \mathrm{mmol})$ and the reaction mixture was stirred at room temperature for $4 \mathrm{~d}$. The solvent was evaporated under vacuum and the ${ }^{1} \mathrm{H}$ NMR spectrum of the crude residue revealed a 70/30 mixture of endo/exo formyl derivative. The chromatographic separation of the resulting mixture using hexane/ethyl acetate as eluent in a gradient form (6:4 to $1: 1)$ supplied the major stereoisomer $(1 S, 2 S, 4 R)-7$ in $66 \%$ yield (133 mg, $0.46 \mathrm{mmol}$ ) as a colorless oil and allowed recovery of the starting material $(1 S, 2 R, 4 R)-7(57 \mathrm{mg})$ [the spectroscopic data for epimer $(1 S, 2 R, 4 R)-7$ are identical to those described in the literature $]{ }^{7 \mathrm{f}}[\alpha]_{\mathrm{D}}=+146.8\left(c 0.5 \mathrm{CHCl}_{3}\right)$; IR (neat) $v\left(\mathrm{~cm}^{-1}\right): 1741,1651,1616$, 1575. ${ }^{1} \mathrm{H}$ NMR $\left(\mathrm{CDCl}_{3}\right) \delta(\mathrm{ppm}): 10.01(\mathrm{~s}, 1 \mathrm{H}), 7.69-7.67(\mathrm{~m}, 2 \mathrm{H}), 7.53-7.48(\mathrm{~m}, 1 \mathrm{H}), 7.43-$ $7.40(\mathrm{~m}, 2 \mathrm{H}), 4.29(\mathrm{dd}, 1 \mathrm{H}, J=4.9 \mathrm{~Hz}, J=4.9 \mathrm{~Hz}), 3.87(\mathrm{~s}, 3 \mathrm{H}), 3.79(\mathrm{ddd}, 1 \mathrm{H}, J=11.4 \mathrm{~Hz}, J=$ $4.4 \mathrm{~Hz}, J=2.8 \mathrm{~Hz}), 2.30-2.21(\mathrm{~m}, 1 \mathrm{H}), 2.16-2.07(\mathrm{~m}, 2 \mathrm{H}), 1.85-1.70(\mathrm{~m}, 2 \mathrm{H}), 1.59$ (ddd, $1 \mathrm{H}, J$ $=11.9 \mathrm{~Hz}, J=9.2 \mathrm{~Hz}, J=4.6 \mathrm{~Hz}) .{ }^{13} \mathrm{C} \mathrm{NMR}\left(\mathrm{CDCl}_{3}\right) \delta(\mathrm{ppm}): 201.0,172.6,170.6,133.8$, $132.0,128.7,128.5,69.0,62.8,53.5,52.9,31.3,30.0,29.3$. HRMS (ESI) $\mathrm{C}_{16} \mathrm{H}_{17} \mathrm{NO}_{4} \mathrm{Na}[\mathrm{M}+$ $\mathrm{Na}]^{+}$calcd. 310.104979, found 310.105584 .

Methyl (1S,2S,4R)- $N$-benzoyl-2-hydroxymethyl-7-azabicyclo[2.2.1]heptane-1-carboxylate (8). To a solution of methyl (1S,2S,4R)- $N$-benzoyl-2-formyl-7-azabicyclo[2.2.1] heptane-1carboxylate $(7)(100 \mathrm{mg}, 0.35 \mathrm{mmol})$ in methanol $(6 \mathrm{~mL})$ and water $(1 \mathrm{~mL})$ at $0{ }^{\circ} \mathrm{C}$ was added $\mathrm{NaBH}_{4}(6.8 \mathrm{mg}, 0.17 \mathrm{mmol})$ and the mixture was stirred for $1 \mathrm{~h}$ at this temperature. The reaction mixture was neutralised by addition of an aqueous solution of $0.5 \mathrm{M}$ hydrochloric acid and the methanol was evaporated under vacuum. Water $(25 \mathrm{~mL})$ was added and the mixture extracted with dichloromethane $(3 \times 25 \mathrm{~mL})$. The combined organic layers were dried over anhydrous magnesium sulfate, filtered and evaporated under vacuum. The residue obtained was purified by flash chromatography on silica gel using ether/ethanol $(9: 1)$ as eluent to afford the alcohol $(1 S, 2 S, 4 R)-8(98 \mathrm{mg}, 0.34 \mathrm{mmol})$ as a white solid in $97 \%$ yield. $\mathrm{Mp}=102-103{ }^{\circ} \mathrm{C} ;[\alpha]_{\mathrm{D}}=+67.4$ $\left(c 0.5 \mathrm{CHCl}_{3}\right)$; IR $(\mathrm{KBr}) \vee\left(\mathrm{cm}^{-1}\right): 3453,1739,1626,1573 .{ }^{1} \mathrm{H} \mathrm{NMR}\left(\mathrm{CDCl}_{3}\right) \delta(\mathrm{ppm}): 7.62-7.60$ $(\mathrm{m}, 2 \mathrm{H}), 7.45-7.41(\mathrm{~m}, 1 \mathrm{H}), 7.36-7.33(\mathrm{~m}, 2 \mathrm{H}), 4.20(\mathrm{dd}, 1 \mathrm{H}, J=5.0 \mathrm{~Hz}, J=5.0 \mathrm{~Hz}), 3.82-3.78$ $(\mathrm{m}, 1 \mathrm{H}), 3.80(\mathrm{~s}, 3 \mathrm{H}), 3.60(\mathrm{dd}, 1 \mathrm{H}, J=10.1 \mathrm{~Hz}, J=10.1 \mathrm{~Hz}), 3.11$ (br s, 1H), 3.04-2.95 (m, $1 \mathrm{H}), 2.26-2.18(\mathrm{~m}, 1 \mathrm{H}), 2.17-2.11(\mathrm{~m}, 1 \mathrm{H}), 2.08-1.99(\mathrm{~m}, 1 \mathrm{H}), 1.98-1.90(\mathrm{~m}, 1 \mathrm{H}), 1.49$ (ddd, $1 \mathrm{H}, J=12.2 \mathrm{~Hz}, J=9.0 \mathrm{~Hz}, J=5.1 \mathrm{~Hz}), 1.01(\mathrm{dd}, 1 \mathrm{H}, J=12.2 \mathrm{~Hz}, J=5.1 \mathrm{~Hz}) .{ }^{13} \mathrm{C}$ NMR 
$\left(\mathrm{CDCl}_{3}\right) \delta(\mathrm{ppm}): 173.0,172.1,134.3,131.6,128.6,128.4,69.9,63.2,61.7,52.8,43.8,34.9$, 30.9, 26.2. HRMS (ESI) $\mathrm{C}_{16} \mathrm{H}_{19} \mathrm{NO}_{4} \mathrm{Na}[\mathrm{M}+\mathrm{Na}]^{+}$calcd. 312.120629, found 312.121756.

Methyl (1S,2S,4R)- $N$-benzoyl-2-bromomethyl-7-azabicyclo[2.2.1]heptane-1-carboxylate (9). $N$-Bromosuccinimide $(124.6 \mathrm{mg}, 0.70 \mathrm{mmol})$ and triphenylphosphine (183.4 $\mathrm{mg}, 0.70 \mathrm{mmol})$ were added to a solution of methyl (1S,2S,4R)- $N$-benzoyl-2-hydroxymethyl-7azabicyclo[2.2.1]heptane-1-carboxylate $(8)(100 \mathrm{mg}, 0.35 \mathrm{mmol})$ in dry THF $(5 \mathrm{~mL})$ under an argon atmosphere and the resulting mixture was stirred at $40{ }^{\circ} \mathrm{C}$ for $12 \mathrm{~h}$. The solvent was removed and the resulting suspension was poured into water $(25 \mathrm{~mL})$ and extracted with dichloromethane $(3 \times 25 \mathrm{~mL})$. The combined organic layers were dried with anhydrous magnesium sulfate, filtered and the solvent was removed under vacuum. Purification of the crude mixture by silica gel column chromatography eluting with a 7:3 mixture of hexane/ethyl acetate gave the bromide $(1 S, 2 S, 4 R)-9$ as a white solid in $80 \%$ yield $(11.5 \mathrm{mg}, 0.28 \mathrm{mmol})$. $\mathrm{Mp}=177-$ $178{ }^{\circ} \mathrm{C} ;[\alpha]_{\mathrm{D}}=+19.0\left(c 0.5 \mathrm{CHCl}_{3}\right)$; IR $(\mathrm{KBr}) \vee\left(\mathrm{cm}^{-1}\right): 1739,1635$. ${ }^{1} \mathrm{H} \mathrm{NMR}\left(\mathrm{CDCl}_{3}\right) \delta(\mathrm{ppm})$ : $7.68-7.65(\mathrm{~m}, 2 \mathrm{H}), 7.51-7.46(\mathrm{~m}, 1 \mathrm{H}), 7.42-7.38(\mathrm{~m}, 2 \mathrm{H}), 4.25(\mathrm{dd}, 1 \mathrm{H}, J=5.0 \mathrm{~Hz}, J=5.0 \mathrm{~Hz})$, $3.82(\mathrm{~s}, 3 \mathrm{H}), 3.64(\mathrm{dd}, 1 \mathrm{H}, J=9.8 \mathrm{~Hz}, J=5.4 \mathrm{~Hz}), 3.34(\mathrm{dd}, 1 \mathrm{H}, J=9.9 \mathrm{~Hz}, J=9.9 \mathrm{~Hz}), 3.22-$ $3.13(\mathrm{~m}, 1 \mathrm{H}), 2.55-2.38(\mathrm{~m}, 2 \mathrm{H}), 2.03(\mathrm{ddd}, 1 \mathrm{H}, J=13.2 \mathrm{~Hz}, J=9.0 \mathrm{~Hz}, J=4.3 \mathrm{~Hz}), 1.98-1.89$ $(\mathrm{m}, 1 \mathrm{H}), 1.54(\mathrm{ddd}, 1 \mathrm{H}, J=12.3 \mathrm{~Hz}, J=9.0 \mathrm{~Hz}, J=4.9 \mathrm{~Hz}), 1.28(\mathrm{dd}, 1 \mathrm{H}, J=12.5 \mathrm{~Hz}, J=5.1$ $\mathrm{Hz}) .{ }^{13} \mathrm{C} \mathrm{NMR}\left(\mathrm{CDCl}_{3}\right) \delta(\mathrm{ppm}): 172.0,170.5,134.1,131.7,128.6,128.4,70.1,62.0,52.6,45.6$, 37.7, 32.9, 30.7, 25.3. HRMS (ESI) C16H18BrNO3Na $[\mathrm{M}+\mathrm{Na}]^{+}$calcd. 374.036227, found 374.037391 .

Methyl (1S,2S,4R)- $N$-benzoyl-2-methyl-7-azabicyclo[2.2.1]heptane-1-carboxylate (10). A solution of methyl (1S,2S,4R)-N-benzoyl-2-bromomethyl-7-azabicyclo[2.2.1]heptane-1carboxylate (9) (100 mg, $0.28 \mathrm{mmol})$ and $\mathrm{NaBH}_{4}(31.8 \mathrm{mg}, 0.84 \mathrm{mmol})$ in HMPA (4 mL) was heated at $70{ }^{\circ} \mathrm{C}$ for $12 \mathrm{~h}$. The solution was allowed to cool down to room temperature and the resulting mixture was diluted with water $(20 \mathrm{~mL})$. The mixture was extracted with dichloromethane $(3 \times 10 \mathrm{~mL})$. The combined organic layers were washed with water $(10 \mathrm{ml})$, dried over anhydrous magnesium sulfate, filtered and the solvent was removed under vacuum. Finally, the residue was purified by chromatography using 9:1 dichloromethane/ethyl acetate as eluent. Compound $(1 S, 2 S, 4 R)-\mathbf{1 0}$ was isolated as a white solid in $90 \%$ yield $(68.3 \mathrm{mg}, 0.25$ mmol). $\mathrm{Mp}=113-114{ }^{\circ} \mathrm{C} ;[\alpha]_{\mathrm{D}}=-6.9\left(c 0.35 \mathrm{CHCl}_{3}\right)$; IR $(\mathrm{KBr}) \vee\left(\mathrm{cm}^{-1}\right): 1730,1638 .{ }^{1} \mathrm{H} \mathrm{NMR}$ $\left(\mathrm{CDCl}_{3}\right) \delta(\mathrm{ppm}): 7.66-7.64(\mathrm{~m}, 2 \mathrm{H}), 7.48-7.44(\mathrm{~m}, 1 \mathrm{H}), 7.40-7.36(\mathrm{~m}, 2 \mathrm{H}), 4.17(\mathrm{dd}, 1 \mathrm{H}, J=$ $5.1 \mathrm{~Hz}, J=5.1 \mathrm{~Hz}), 3.79(\mathrm{~s}, 3 \mathrm{H}), 2.79-2.69(\mathrm{~m}, 1 \mathrm{H}), 2.34-2.18(\mathrm{~m}, 2 \mathrm{H}), 2.10$ (ddd, $1 \mathrm{H}, J=13.1$ $\mathrm{Hz}, J=9.0 \mathrm{~Hz}, J=4.5 \mathrm{~Hz}), 1.80-1.72(\mathrm{~m}, 1 \mathrm{H}), 1.47(\mathrm{ddd}, 1 \mathrm{H}, J=12.2 \mathrm{~Hz}, J=9.0 \mathrm{~Hz}, J=4.8$ $\mathrm{Hz}), 1.09(\mathrm{~d}, 3 \mathrm{H}, J=7.0 \mathrm{~Hz}), 0.98(\mathrm{dd}, 1 \mathrm{H}, J=11.9 \mathrm{~Hz}, J=5.2 \mathrm{~Hz}) .{ }^{13} \mathrm{C} \mathrm{NMR}\left(\mathrm{CDCl}_{3}\right) \delta(\mathrm{ppm})$ : $172.1,171.3,134.5,131.4,128.6,128.3,70.8,62.6,52.3,38.5,38.3,31.2,24.0$, 15.5. HRMS (ESI) $\mathrm{C}_{16} \mathrm{H}_{19} \mathrm{NO}_{3} \mathrm{Na}[\mathrm{M}+\mathrm{Na}]^{+}$calcd. 296.125715, found 296.126712. 


\section{Acknowledgements}

This work was carried out with the financial support of Ministerio de Ciencia y Tecnología and FEDER (project CTQ2004-5358) and Gobierno de Aragón (Grupo Consolidado E40).

\section{References and footnotes}

1. (a) Giannis, A.; Kolter, T. Angew. Chem. Int. Ed. 1993, 32, 1244. (b) Liskamp, R. M. J. Recl. Trav. Chim. Pays-Bas 1994, 113, 1. (c) Gante, J. Angew. Chem. Int. Ed. Engl. 1994, 33, 1699. (d) Gibson, S. E.; Guillo, N.; Tozer, M. J. Tetrahedron 1999, 55, 585. (e) Hruby, V. J.; Balse, P. M. Curr. Med. Chem 2000, 7, 945. (f) Cowell, S. M.; Lee, Y. S.; Cain, J. P.; Hruby, V. J. Curr. Med. Chem. 2004, 11, 2785. (g) Sagan, S.; Karoyan, P.; Lequin, O.; Chassaing, G.; Lavielle, S. Curr. Med. Chem. 2004, 11, 2799.

2. (a) Rose, G. D.; Gierasch, L. M.; Smith, J. A. Adv. Protein Chem. 1985, 37, 1. (b) Aubry, A.; Cung, M. T. Marraud, M. J. Am. Chem. Soc. 1985, 107, 7640. (c) Marraud, M.; Aubry, A. Biopolymers 1996, 40, 45. (d) Baures, P. W.; Ojala, W. J.; Gleason, W. B.; Johnson, R. L. J. Pept. Res. 1997, 50, 1. (e) Beausoleil. E.; Sharma. R.; Michnick, S. W.; Lubell, W. D. J. Org. Chem. 1998, 63, 6572. (f) Halab, L.; Lubell, W. D. J. Org. Chem. 1999, 64, 3312.

3. (a) Han, W.; Pelletier, J. C.; Mersinger, L. J.; Hodge, C. N. Bioorg. Med. Chem. Lett. 1998, 8, 3615. (b) Han, W.; Pelletier, J. C.; Mersinger, L. J.; Kettner, C. A.; Hodge, C. N. Org. Lett. 1999, 1, 1875. (c) Gil, A. M.; Buñuel, E.; Jiménez, A. I.; Cativiela, C. Tetrahedron Lett. 2003, 44, 5999. (d) Gil, A. M.; Buñuel, E.; Jiménez, A. I.; Cativiela, C. Third International and Twenty-Eighth European Peptide Symposium; Flegel, M.; Fridkin, M.; Gilon, C.; Slaninova, J. Eds; Kenes International: Tel Aviv, 2005; pp. 222.

4. (a) Kolodziej, S. A.; Nikiforovich, G. V.; Skeean, R; Lignon, M.-F.; Martinez, J.; Marshall, G. R. J. Med. Chem. 1995, 38, 137. (b) Marshall, G. R. Tetrahedron 1993, 49, 3547. (c) Plucinska, K.; Kataoka, T.; Yodo, M.; Cody, W. L.; He, J. X.; Humblet, C.; Lu, G. H.; Lunney, E.; Major, T. C.; Panek, R. L.; Schelkun, P.; Skeean, R.; Marshall, G. R. J. Med. Chem. 1993, 36, 1902. (d) Kaczmarek, K.; Li, K.-M.; Sheean, R.; Dooley, D.; Humblet, C.; Lunney, E.; Marshall, G. R. In Peptides: Chemistry, Structure and Biology; Hodges, R. S., Smith, J. A., Eds.; ESCOM Science Publishers B. V.: Leiden, The Netherlands, 1994; pp 687. (e) Mosberg, H. I.; Lomize, A. L.; Wang, C.; Kroona, H.; Heyl, D. L.; Sobczyk-Kojiro, K.; Ma, W.; Mousigian, C.; Porreca, F. J. Med. Chem. 1994, 37, 4371. (f) Nelson, R. D.; Gottlieb, D. I.; Balasubramanian, T. M.; Marshall, G. R. In Opioid Peptides: Medicinal Chemistry, NIDA Research Nonograph 69; Rapaka, R. S. R. S.; Banett, G.; Hawks, R. L., Eds.; 1986, pp 204. (g) Ghose, A. K.; Logan, M. E.; Treasurywala, A. M.; Wang, H.; Wahl, R. C.; Tomczuk, B. E.; Gowravaram, M. R.; Jaeger, E. P.; Wendoloski, J. J. J. Am. Chem. Soc. 1995, 117, 4671. 
5. Spand, T. F.; Garrafo, H. M.; Edwards, M. W.; Daly, J. W. J. Am. Chem. Soc. 1992, 114, 3475.

6. Chen, Z.; Trudell, M. L. Chem. Rev. 1996, 96, 1179.

7. (a) Campbell, J. A.; Rapoport, H. J. Org. Chem. 1996, 61, 6313. (b) Hart, B. P.; Rapoport, H. J. Org. Chem. 1999, 64, 2050. (c) Avenoza, A.; Cativiela, C.; Fernández-Recio, M. A.; Peregrina, J. M. Tetrahedron: Asymmetry 1999, 10, 3999. (d) Lennox, J. R.; Turner, S. C.; Rapoport, H. J. Org. Chem. 2001, 66, 7078. (e) Avenoza, A.; Barriobero, J. I.; Busto, J. H.; Cativiela, C.; Peregrina, J. M. Tetrahedron: Asymmetry 2002, 13, 625. (f) Buñuel, E.; Gil, A. M.; Díaz-de-Villegas, M. D.; Cativiela, C. Tetrahedron 2001, 57, 6417. (g) Gil, A. M.; Buñuel, E.; Cativiela, C. In Targets in Heterocyclic Systems. Chemistry and Properties; Attanasi, O. A.; Spinelli, E. Eds; Royal Society of Chemistry: Cambridge, 2005; pp 56-86.

(h) Gil, A. M., Ph. D. thesis, 2005. University of Zaragoza.

8. (a) Gil, A. M.; Buñuel, E.; López, P.; Cativiela, C. Tetrahedron: Asymmetry 2004, 15, 811. (b) Gil, A. M.; López, P.; Buñuel, E.; Cativiela, C. Arkivoc 2005, (ix), 90.

9. (a) Jiménez, A. I.; Vanderesse, R.; Marraud, M.; Aubry, A.; Cativiela, C.; Tetrahedron Lett. 1997, 38, 7559. (b) Jiménez, A. I.; Cativiela, C.; Aubry, A.; Marraud, M. J. Am. Chem. Soc. 1998, 120, 9452. (c) Jiménez, A. I.; Cativiela, C.; París, M.; Peregrina, J. M.; Avenoza, A.; Aubry, A.; Marraud, M. Tetrahedron Lett. 1998, 39, 7841. (d) Jiménez, A. I.; Cativiela, C.; Gómez-Catalán, J.; Pérez, J. J.; Aubry, A.; París, M.; Marraud, M. J. Am. Chem. Soc. 2000, 122, 5811. (e) Jiménez, A. I.; Cativiela, C.; Marraud, M. Tetrahedron Lett. 2000, 41, 5353. (f) Jiménez, A. I.; Marraud, M.; Cativiela, C. Tetrahedron Lett. 2003, 44, 3147. (g) Lasa, M.; Jiménez, A. I.; Zurbano, M. M.; Cativiela, C.; Tetrahedron Lett. 2005, 46, 8377. (h) Jiménez, A. I.; Ballano, G.; Cativiela, C. Angew. Chem. Int. Ed. 2005, 44, 396.

10. Gil, A. M.; Buñuel, E.; Díaz-de-Villegas, M. D.; Cativiela, C. Tetrahedron: Asymmetry 2003, 14, 1479.

11. Gil, A. M.; Orús, E.; López-Carrillo, V.; Buñuel, E.; Cativiela, C. Tetrahedron: Asymmetry 2005, 16, 3115.

12. Cativiela, C.; Díaz-de-Villegas, M. D. In Oxazolones: Synthesis, Reactions and Spectroscopy. Part B. The Chemistry of Heterocyclic Compounds; Vol. 60. Palmer, D. C. Ed.; John Wiley \& Sons: New York, 2004; pp. 129-330.

13. (a) Fletcher, S. R.; Baker, R.; Chambers, M. S.; Herbert, R. H.; Hobbs, S. C.; Thomas, S. R.; Verrier, H. M.; Watt, A. P.; Ball, R. G. J. Org. Chem. 1994, 59, 1771. (b) Zhang, C.; Trudell, M. L. J. Org. Chem. 1996, 61, 7189. (c) Szántay, C.; Kardos-Balogh, Z.; Moldvai, I.; Szántay, C. Jr.; Temesvári-Major, E.; Blaskó, G. Tetrahedron 1996, 52, 11053. (d) Habermann, J.; Ley, S. V.; Scott, J. S. J. Chem. Soc., Perkin Trans. 1 1999, 1253. (e) Pandey, G.; Sahoo, A. K.; Grade, S. R.; Bagul, T. D.; Phalgune, U. D. J. Org. Chem. 1999, 64, 4990. (f) Olivo, H. F.; Hemenway, M. S. Org. Prep. Proced. Int. 2002, 34, 1. (g) Wei, ZL.; Xiao, Y.; George, C.; Kellar, K. J.; Kozikowski, A. P. Org. Biomol. Chem. 2003, 1, 3878 . 
14. Myers, A. G.; Zhong, B.; Movassaghi, M.; Kung, D. W.; Lanman, B. A.; Kwon, S. Tetrahedron Lett. 2000, 41, 1359.

15. Sheldrick, G. M. SHELXS-97. Program for the solution of crystal structures; University of Göttingen: Germany, 1997.

16. Sheldrick, G. M. SHELXS-97. Program for the refinement of crystal structures; University of Göttingen: Germany, 1997. 